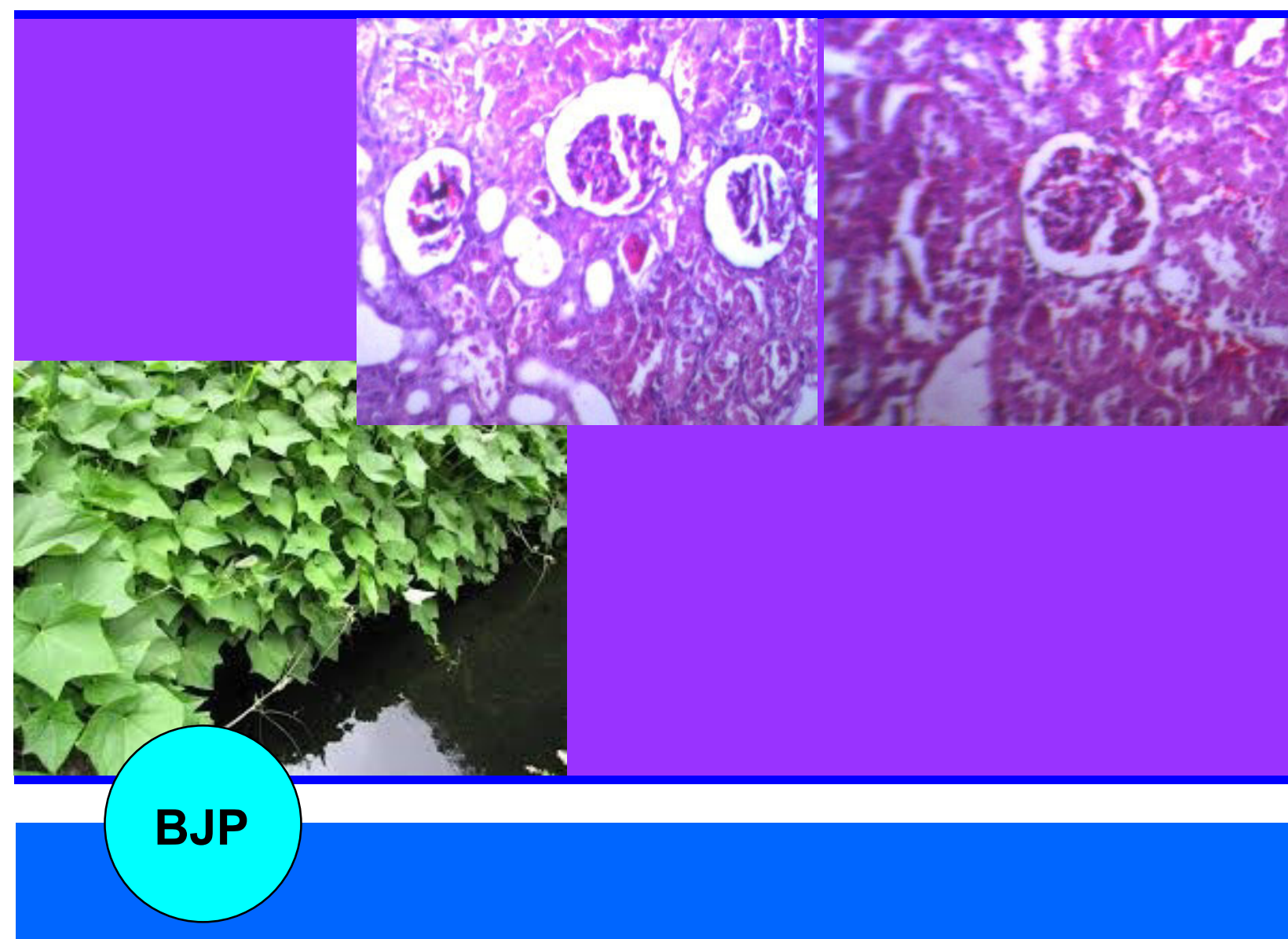

Bangladesh Journal of Pharmacology

Research Article

Effect of Sechium edule on chemical induced kidney damage in experimental animals 


\title{
Effect of Sechium edule on chemical induced kidney damage in experimental animals
}

\author{
S. M. Firdous Mumtaz ${ }^{1}$, Shounak Paul ${ }^{1}$ and Anupam Kanti Bag ${ }^{2}$ \\ ${ }^{1}$ Department of Pharmacology, Calcutta Institute of Pharmaceutical Technology and AHS, Uluberia, Howrah \\ 711 316, West Bengal, India; ${ }^{2}$ Department of Pharmacology, Ratnam Institute of Pharmacy, Pidathapolur \\ Village, Muthukur SPSR Nellore, Andhra Pradesh 524 346, India.
}

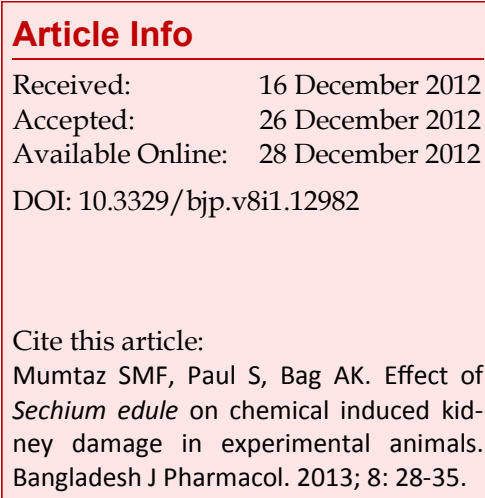

\section{Introduction}

Diabetic nephropathy is the leading cause of chronic renal failure in the industrialised world. It is a serious microvascular complication of diabetes mellitus and is the leading cause of kidney disease in patients starting renal replacement therapy and affects approximately $40 \%$ of type 1 and 2 diabetic patients. Glomerular hypertrophy and hyper filtration are early renal abnormalities in diabetes. The onset of clinical diabetic kidney disease is characterized by an abnormal increase in the urinary albumin excretion rate. Progression to overt nephropathy characteristically occurs over a period of years with the development of heavier proteinuria and subsequent fall in glomerular filtration rate. Excessive extracellular matrix deposition in the mesangium, thickening of the glomerular basement membrane and podocyte abnormalities, eventually resulting in podocyte loss, are characteristic histological features of the complications. Hyperfiltration and microalbuminuria were the first signs of diabetic nephropathy. End-stage kidney and renal failure accounts for deaths in more than $10 \%$ of all diabetes (Abd and Amin, 2011).

Sechium edule is an edible plant that belongs to the family cucurbitaceae also known as chayote, choko, chocho, chow-chow, and vegetable pear. The fruits and the seed especially, are rich in several important amino acids. A lectin from the exudate of S. edule was purified (Vozari-Hampe et al., 1992). Eight flavonoids, including three C-glycosyl and five O-glycosyl flavones, were detected (Siciliano and De Tommasi, 2004). Twenty known Gibberellins' have been identified in extracts of the seeds of S. edule (Albone et al., 1984). The leaves and fruits have diuretic, cardiovascular and anti-inflammatory properties, the leaves has been used in the treatment of arteriosclerosis and hypertension, and to dissolve kidney stones (Kamble et al., 2008; Gordon et al., 2000). The fruits of S. edule have been reported for 
hepatoprotective, antiulcer and free radical scavenging and anti-oxidant activity (Firdous et al., 2012; Firdous et al., 2012; Ordonez et al., 2006).

So, in the present study the effect of aqueous extract of leaves of S. edule was investigated in chemical-induced kidney damage in experimental animals.

\section{Materials and Methods}

\section{Plant material}

Fruits of S. edule were collected from Reliance Fresh, Secunderabad and also from Bangalore. The fruit material was taxonomically identified and authenticated by Dr. Shiddamallayya at Regional Research Institute, Bangalore, where the voucher specimen is conserved under the reference number (RRCBI/MCW/7/2008).

\section{Preparation of the extracts}

The leaves were washed thoroughly with tap water and air dried in shade at room temperature. They were mechanically powdered and sieved. The aqueous extract was prepared by cold maceration (72 hours). The liquid extract obtained was concentrated in vacuum at $40^{\circ} \mathrm{C}$. The yield of extract was $24.0 \%$ and the extract was phytochemically investigated (Harbone, 1998).

\section{Drugs and chemicals}

Gentamicin was procured from Piramal Health Care, Ahmedabad, India. Potassuim dichromate was obtained from E. Merk private limited, Mumbai, India. Glibenclamide was obtained from Sanofi Aventis, Mumbai, India and sreptozotocin was obtained from Himedia, Mumbai, India. Urea, total protein, uric acid and creatinine kits were obtained from Span Diagnostics, Surath, India. All other chemicals used in this study were obtained commercially and were of analytical grade.

\section{Experimental animals}

Albino rats (Wistar) weighing 150-200 g and albino mice weighing 20-25 g of either sex were used in this study. Animals were maintained under controlled conditions of temperature $\left(23 \pm 2{ }^{\circ} \mathrm{C}\right)$ and humidity $(50 \pm$ $5 \%$ ) and a 12 hours light-dark cycle, were used for the experiment. They were housed in sanitised polypropylene cages containing sterile paddy husk as bedding. They had free access to standard rat pellet diet and water ad libitum. The animals were given a week's time to get acclimatized with the laboratory conditions. All the experimental procedures were performed according to the committee for the purpose of control and supervision of experiments on animals (CPCSEA), ministry of social justice and empowerment Government of India, norms and approved by the Institutional
Animal Ethics Committee (IAEC).

\section{Acute toxicity studies}

Animals were kept overnight fasting prior to drug administration and then they received a single oral dose $(2,000 \mathrm{mg} / \mathrm{kg}$, b.w.) of aqueous extract of $S$. edule leaves. After the administration of extract food was withheld for further 3-4 hours. Animals were observed individually at least once during the first 30 min after dosing, periodically during the first 24 hours (with special attention during the first 4 hours) and daily thereafter for a period of 14 days. Once daily cage side observations included changes in skin and fur, eyes and mucous membrane (nasal) and also respiratory rate, circulatory (heart rate and blood pressure), autonomic (salivation, lacrimation, perspiration, piloerection, urinary incontinence, and defecation) and central nervous system (ptosis, drowsiness, gait, tremors and convulsion) changes. Mortality, if any, was determined over a period of 2 weeks (OECD, 2002).

\section{Gentamicin-induced nephrotoxicity in rats}

Twenty four Wistar albino rats of either sex were assigned to four groups $(n=6)$ : Group 1: Rats in this group were injected with normal saline, intraperitonealy and served as control.

Group 2: Rats in this group were injected with gentamicin (100 mg/kg, b.w, i.p) for seven consecutive days; Group 3: Rats in this group were injected with gentamicin (100 mg/kg, b.w, i.p) and administered aqueous extract of $S$. edule (200 mg/ kg, b.w, p.o) for seven consecutive days; Group 4: Rats in this group were injected with gentamicin $(100 \mathrm{mg} / \mathrm{kg}$, b.w, i.p) and administered aqueous extract of $S$. edule $(100 \mathrm{mg} /$ $\mathrm{kg}$, b.w, p.o) for seven consecutive days.

After the last dosing of seventh day after 24 hours the blood sample were collected by puncturing retro-orbital plexus and serum was separated by centrifugation. Rats were sacrificed; kidneys were excised, rinsed clean in saline and preserved in $10 \%$ formalin for histopathological study (Harlalka et al., 2007).

\section{Potassium dichromate-induced nephrotoxicity in rat}

Twenty four Wistar albino rats of either sex were assign to four groups $(n=6)$ : Group 1: Served as control group, animals in which were injected with sterile saline solution as a single dose, subcutaneously; Group 2: Considered as toxicant group and pre-treated with saline followed by a single subcutaneous injection of potassium dichromate (15 mg/ $\mathrm{kg}$, s.c) and observed for five days post dosing; Group 3: Rats in this group were injected with a single dose potassium dichromate (15 $\mathrm{mg} / \mathrm{kg}, \mathrm{s.c}$ ) and then treated with the aqueous extract of S. edule (200 mg/kg, p.o) for five consecutive days; Group 4: Rats in this group were injected with with a single dose potassium dichromate $(15 \mathrm{mg} / \mathrm{kg}$, s.c) and 
then treated with the aqueous extract of S. edule (100 $\mathrm{mg} / \mathrm{kg}$, p.o) for five consecutive days.

After the last dosing of fifth day after 24 hours the blood sample were collected by puncturing retro-orbital plexus and serum was separated by centrifugation. Rats were sacrificed; kidneys were excised, rinsed clean in saline and preserved in $10 \%$ formalin for histopathological study (Parveen et al., 2009).

\section{Streptozotocin-induced diabetic nephropathy in rat}

Diabetes was induced in Swiss albino mice by a single intraperitoneal injection of freshly prepared STZ (55 $\mathrm{mg} / \mathrm{kg}$, i.p) in citrate buffer $(\mathrm{pH} 4.5)$ in a volume of 1 $\mathrm{mL} / \mathrm{kg}$ (Siddiqui et al., 1987). Streptozotocin injected animals were given $10 \%$ glucose solution for 5 days to prevent initial drug induced hyperglycemic mortality. Diabetes was confirmed in STZ mice by measuring the fasting blood glucose concentration, after 48 hours of injection with STZ. Mice with a blood glucose level above $180 \mathrm{mg} / \mathrm{dL}$ were considered to be diabetic and used in the experiment.

In the experiment, a total number of 30 mice were divided into 5 groups $(n=6)$. Group 1: Normal control mice were treated with citrate buffer intraperitonealy; Group 2: Served as diabetic control group treated with single dose of streptozotocin (55 mg/kg, i.p); Group 3: Diabetic mice treated with glibenclamide $(10 \mathrm{mg} / \mathrm{kg}$, p.o.) for a period of 30 days; Group 4: Diabetic mice treated with aqueous extract of $S$. edule $(200 \mathrm{mg} / \mathrm{kg}$, p.o) for 30 consecutive days; Group 5: Diabetic mice treated with aqueous extract of $S$. edule $(100 \mathrm{mg} / \mathrm{kg}$, p.o) for 30 consecutive days.

After the last dosing of $30^{\text {th }}$ day after 24 hours the blood sample were collected by puncturing retro-orbital plexus and serum was separated by centrifugation. Mice were sacrificed; kidneys were excised, rinsed clean in saline and preserved in $10 \%$ formalin for histopathological study (Wilson et al., 2011).

\section{Biochemical studies}

The blood was obtained from all animals by puncturing retro-orbital plexus. Serum was separated by centrifu- gation at 2,500 rpm for $15 \mathrm{~min}$ and then various biochemical parameters such as serum creatinine, blood urea, blood urea nitrogen, uric acid and total protein were evaluated.

\section{Histopathological studies kidneys}

After the animals were sacrificed the kidneys from all groups were identified and carefully dissected out for histopathological examination. After rinsing in normal saline, sections were taken from each harvested kidney. The tissue was fixed in 10\% formalin and embedded in paraffin. Microtome sections (4-5 $\mu \mathrm{m}$ thick) were prepared from each kidney sample and stained with haemtoxylin-eosin dye and observed under a computerized light microscope to evaluate the details of renal architecture in each group microscopically.

\section{Statistical analysis}

Results were expressed Mean \pm SEM from six animals in each group. Comparison between the groups were made by using one-way analysis of variance (ANOVA), followed by Tukey-Kramer Multiple Comparisons Test with the help of INSTAT software. $\mathrm{p}<0.05$ was considered as statistically significant.

\section{Results}

In LD50 studies, it was found that the animals were safe up to a maximum dose of $2,000 \mathrm{mg} / \mathrm{kg}$ body weight. There were no changes in normal behaviour pattern and no signs and symptoms of toxicity and mortality were observed. Thus, $1 / 10^{\text {th }}$ and $1 / 20^{\text {th }}$ doses i.e. 200 $\mathrm{mg} / \mathrm{kg}$ and $100 \mathrm{mg} / \mathrm{kg}$ were selected for all further invivo studies.

In gentamicin-induced nephrotoxicity, gentamicintreated group showed a significant $(\mathrm{p}<0.001)$ increase in blood urea, blood urea nitrogen and serum creatinine as compared to control group and the total serum protein concentration was significantly $(p<0.001)$ lower in gentamycin treated group. Administering aqueous extract of $S$. edule significantly $(\mathrm{p}<0.001)$ reduced the levels of blood urea, blood urea nitrogen and serum

Table I

Effect of aqueous extract of leaves of Sechium edule on biochemical parameters in gentamicin-induced ne-

\begin{tabular}{|lcccc|}
\hline Treatment design & $\begin{array}{c}\text { Blood urea } \\
(\mathrm{mg} / \mathrm{dL})\end{array}$ & $\begin{array}{c}\text { Blood urea nitrogen } \\
(\mathrm{mg} / \mathrm{dL})\end{array}$ & $\begin{array}{c}\text { Serum creatinine } \\
(\mathrm{mg} / \mathrm{dL})\end{array}$ & $\begin{array}{c}\text { Total protein } \\
(\mathrm{mg} / \mathrm{dL})\end{array}$ \\
\hline Normal control & $18.8 \pm 1.2$ & $8.8 \pm 0.6$ & $0.4 \pm 0.0$ & $7.1 \pm 0.2$ \\
Gentamicin $(100 \mathrm{mg} / \mathrm{kg})$ & $80.2 \pm 3.2^{\mathrm{a}}$ & $37.4 \pm 1.5^{\mathrm{a}}$ & $2.4 \pm 0.2^{\mathrm{a}}$ & $3.4 \pm 0.1^{\mathrm{a}}$ \\
Aquous extract $(200 \mathrm{mg} / \mathrm{kg})$ & $40.3 \pm 2.0^{\mathrm{b}}$ & $18.8 \pm 0.9^{\mathrm{b}}$ & $0.8 \pm 0.0^{\mathrm{b}}$ & $5.4 \pm 0.1^{\mathrm{b}}$ \\
Aquous extract $(100 \mathrm{mg} / \mathrm{kg})$ & $63.8 \pm 2.0^{\mathrm{b}}$ & $29.8 \pm 0.9^{\mathrm{b}}$ & $1.4 \pm 0.1^{\mathrm{b}}$ & $4.4 \pm 0.1^{\mathrm{b}}$ \\
$\begin{array}{l}\text { Values are expressed as mean } \pm \mathrm{SEM} ; \mathrm{n}=6 \text {; }{ }^{\mathrm{b}}<0.001 \text { considered statistically significant as compared to normal control group; }{ }^{\mathrm{b}} \mathrm{p}<0.001 \text { consid- } \\
\text { ered statistically significant as compared to gentamicin treated group }\end{array}$ \\
\hline
\end{tabular}


Table II

Effect of aqueous extract of leaves of Sechium edule on biochemical parameters in potassium dichromateinduced nephrotoxicity in rats

\begin{tabular}{|lcccc|}
\hline Treatment design & $\begin{array}{c}\text { Blood urea } \\
(\mathrm{mg} / \mathrm{dL})\end{array}$ & $\begin{array}{c}\text { Blood urea nitrogen } \\
(\mathrm{mg} / \mathrm{dL})\end{array}$ & $\begin{array}{c}\text { Serum creatinine } \\
(\mathrm{mg} / \mathrm{dL})\end{array}$ & $\begin{array}{c}\text { Total protein } \\
(\mathrm{mg} / \mathrm{dL})\end{array}$ \\
\hline Normal control & $25.1 \pm 2.0$ & $17.0 \pm 5.7$ & $1.0 \pm 0.0$ & $6.8 \pm 0.2$ \\
Potassium dichromate $(15 \mathrm{~g} / \mathrm{kg})$ & $61.2 \pm 3.2^{\mathrm{a}}$ & $28.6 \pm 1.5^{\mathrm{a}}$ & $2.1 \pm 0.1^{\mathrm{a}}$ & $3.0 \pm 0.1^{\mathrm{a}}$ \\
Aqueous extract $(200 \mathrm{mg} / \mathrm{kg})$ & $37.0 \pm 1.8^{\mathrm{b}}$ & $17.3 \pm 0.8^{\mathrm{b}}$ & $1.3 \pm 0.0^{\mathrm{b}}$ & $5.2 \pm 0.3^{\mathrm{b}}$ \\
Aqueous extract $(100 \mathrm{mg} / \mathrm{kg})$ & $52.2 \pm 2.3$ & $24.4 \pm 1.1$ & $2.0 \pm 0.1^{\mathrm{b}}$ & $4.2 \pm 0.1^{\mathrm{b}}$ \\
$\begin{array}{l}\text { Values are expressed as mean } \pm \mathrm{SEM}, \mathrm{n}=6 \text {; } \text { ap }<0.001 \text { considered statistically significant as compared to normal control group; bp<0.001 consid- } \\
\text { ered statistically significant }\end{array}$ & & &
\end{tabular}

Table III

Effect of aqueous extract of leaves of Sechium edule on biochemical parameters in streptozotocin-induced dia-

\begin{tabular}{|c|c|c|c|c|c|}
\hline Treatment design & $\begin{array}{l}\text { Blood urea } \\
(\mathrm{mg} / \mathrm{dL})\end{array}$ & $\begin{array}{l}\text { Blood urea nitrogen } \\
(\mathrm{mg} / \mathrm{dL})\end{array}$ & $\begin{array}{l}\text { Serum creatinine } \\
(\mathrm{mg} / \mathrm{dL})\end{array}$ & $\begin{array}{l}\text { Uric acid } \\
(\mathrm{mg} / \mathrm{dL})\end{array}$ & $\begin{array}{l}\text { Total protein } \\
(\mathrm{mg} / \mathrm{dL})\end{array}$ \\
\hline Normal control & $21.7 \pm 1.7$ & $10.1 \pm 0.8$ & $0.7 \pm 0.1$ & $1.4 \pm 0.1$ & $6.1 \pm 0.2$ \\
\hline Streptozotocin (55 mg/kg) & $40.1 \pm 1.4^{a}$ & $19.1 \pm 0.6^{a}$ & $2.5 \pm 0.1^{\mathrm{a}}$ & $2.7 \pm 0.1^{\mathrm{a}}$ & $3.0 \pm 0.1^{\mathrm{a}}$ \\
\hline Glibenclamide (10 mg/kg) & $28.5 \pm 1.3^{b}$ & $13.3 \pm 0.6^{b}$ & $1.1 \pm 0.0^{\mathrm{b}}$ & $2.0 \pm 0.1^{b}$ & $5.1 \pm 0.1^{b}$ \\
\hline Aqueous extract $(200 \mathrm{mg} / \mathrm{kg})$ & $31.1 \pm 1.1^{b}$ & $14.5 \pm 0.5^{b}$ & $1.1 \pm 0.0^{\mathrm{b}}$ & $1.9 \pm 0.1^{b}$ & $5.1 \pm 0.2^{\mathrm{b}}$ \\
\hline Aqueous extract $(100 \mathrm{mg} / \mathrm{kg})$ & $38.7 \pm 1.0$ & $18.1 \pm 0.5$ & $1.8 \pm 0.1^{b}$ & $2.3 \pm 0.1^{b}$ & $4.0 \pm 0.3^{c}$ \\
\hline
\end{tabular}

creatinine in gentamicin-treated rats as compared to the animals treated with gentamicin-treated group alone and the total serum protein concentration was significantly $(\mathrm{p}<0.001)$ increased (Table I).

The levels of blood urea, blood urea nitrogen and serum creatinine in normal and potassium dichromate intoxicated rats (Table II). Rats intoxicated with potassium dichromate, showed a significant $(\mathrm{p}<0.001)$ increase in the levels of blood urea, blood urea nitrogen and serum creatinine when compared to normal rats and the serum level of total protein concentration was significantly $(p<0.001)$ lower in potassium dichromate intoxicated rats. Administering aqueous extract of $S$. edule significantly $(\mathrm{p}<0.001)$ reduced the levels of blood urea, blood urea nitrogen and serum creatinine in gentamicin treated rats as compared with potassium dichromate intoxicated rats. The serum level of total protein concentration was overcome significantly $(\mathrm{p}<0.001)$ with treatment of aqueous extract of S. edule.

The effect of aqueous extract of $S$. edule on various biochemical parameters in streptozotocin-induced diabetic nephropathy in mice (Table III). Mice induced with STZ, showed a significant $(\mathrm{p}<0.001)$ increase in the levels of blood urea, serum creatinine and uric acid when compared to normal mice. Diabetic mice treated with aqueous extract of S. edule $(200 \mathrm{mg} / \mathrm{kg})$ showed significant $(p<0.001)$ reduction in the levels of blood urea, blood urea nitrogen, serum creatinine and uric acid when compared with diabetic control mice. Diabetic mice showed a significant $(p<0.001)$ decrease in serum total protein which was overcome was overcome significantly $(\mathrm{p}<0.001)$ with treatment of aqueous extract of $S$. edule.

\section{Histopathological observation of kidney}

In gentamicin induce nephrotoxicity model normal control rats (Figure 1A) showed normal glomerular and tubular histology whereas gentamycin treated group was found to cause distorted tubular shape, cellular infiltration of the tubules (tubulitis), glomerular and blood vessel congestion, and also result in the presence of inflammatory cells in kidney sections (Figure 1B). The concurrent treatment with the aqueous extract of leaves of $S$. edule $(200 \mathrm{mg} / \mathrm{kg}$, p.o.) reduced such changes in kidney histology (Figure 1C).

In rats treated with potassium dichromate, the nephrotoxicity was evidenced by distorted tubular shape, cellular infiltration of the tubules (tubulitis), tubular damage manifested swollen and necrotic epithelial cell in tubular lumen and expanded mesangium in glumeruli (Figure 2B). Treatment with the aqueous extract of leaves of S. edule (200 mg/ kg, p.o.) reduced such pathological changes in kidney histology (Figure 2C). 


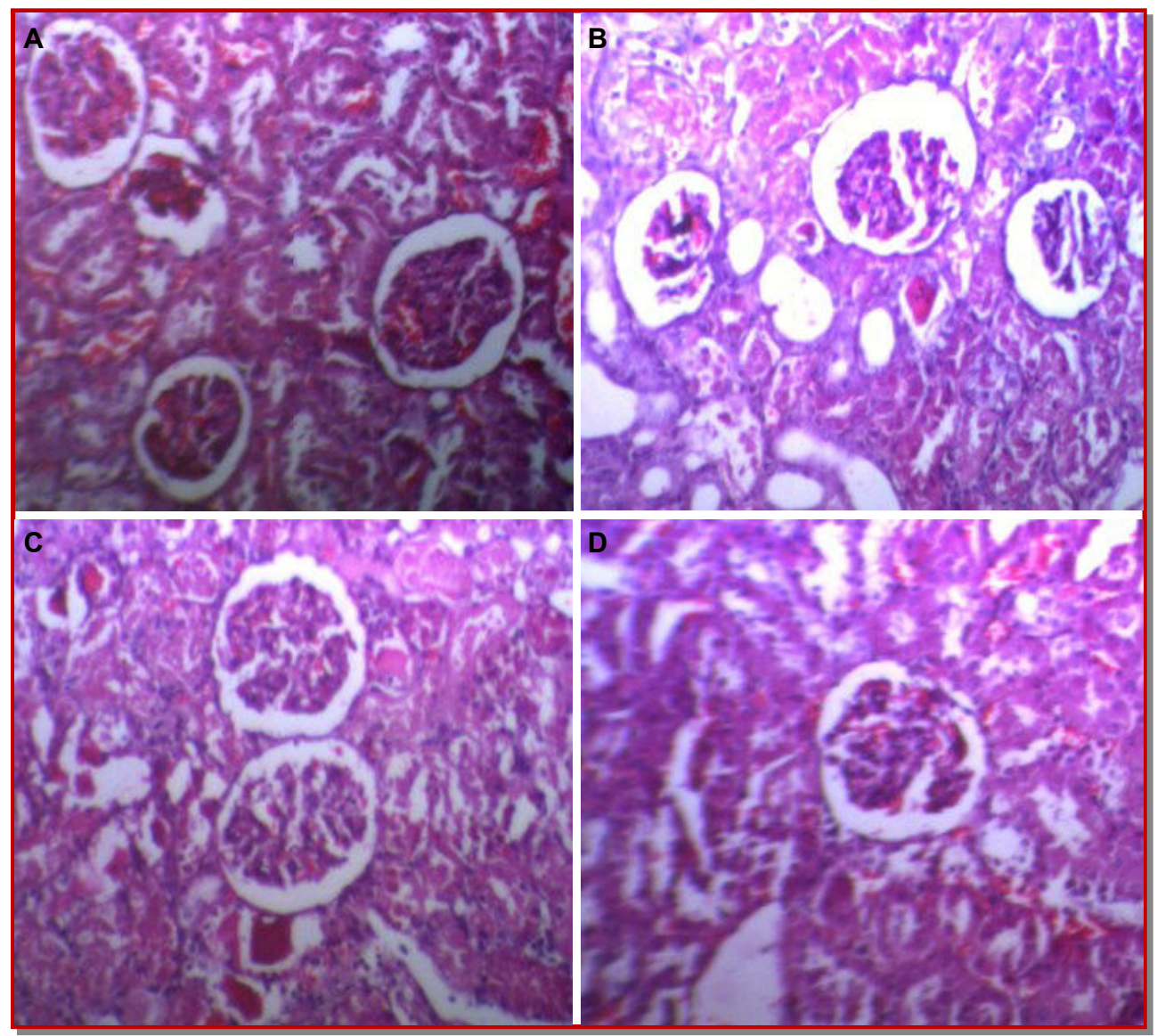

Figure 1: Effect of aqueous extract of leaves of Sechium edule on gentamicin-induced nephrotoxicity in rats

A: Normal control; B: Treated with gentamicin (100 mg/kg, i.p.); C: Treated with Sechium edule (200 mg/kg) and gentamicin (100 mg/kg, i.p.); D: Treated with Sechium edule $(100 \mathrm{mg} / \mathrm{kg})$ and gentamicin $(100 \mathrm{mg} / \mathrm{kg}$, i.p.)

The normal control mice (Figure 3A) in diabetic nephropathy model showed the intact tubules and glomeruli whereas STZ treated group was found to cause degenerating tubules with desquamated epithelial cells in the lumen and glomerular congestion. Mice treated with STZ shows degenerating tubules with desquamated epithelial cells in the lumen (Figure 3B). Streptozotocininduced diabetic mice treated with glibenclamide (10 $\mathrm{mg} / \mathrm{kg}$, p.o.) and the aqueous extract of leaves of $S$. edule (200 mg/kg, p.o.) showed the almost intact tubules and glomeruli (Figure 3C-D).

\section{Discussion}

Gentamicin-induced nephrotoxicity is characterized by a decrease in the glomerular filtration rate and direct tubular injury due to the formation of reactive oxygen species (ROS), which may be directly involved in membrane lipid peroxidation, mesangial cells contraction, alter the filtration surface area and modify the ultrafiltration coefficient and decrease the glomerular filtration rate (Poormoosavi et al., 2010).
Potassium dichromate in rats induced an increase in $\mathrm{Cr}$ kidney content and produced anatomical lesions at the level of the proximal tubular cells (Pedraza-Chaverri et al., 2005; Franchini et al., 1978). Cr (VI) compounds are easily taken up by the cells and are subsequently reduced to $\mathrm{Cr}$ (III) species. This reduction generates free radicals, which play a major role in the adverse biological effects (Shi et al., 1999).

Our study results show that aqueous extract of leaves of S. edule possess nephroprotective activity against gentamicin-induced nephrotoxicity which may due to antioxidant potential of reported flavonoids such as Cglycosyl and O-glycosyl flavones which are present in the of leaves of S. edule (Siciliano and De Tommasi, 2004).

Abnormal renal hemodynamics occurs in the early stages of diabetic nephropathy, and progresses to proteinuria, glomerulosclerosis, and renal dysfunction. Therefore, management of renal hemodynamic abnormality and reduction of proteinuria are important to prevent the deterioration of kidney function. Degradation of protein and nucleic acid results in the 


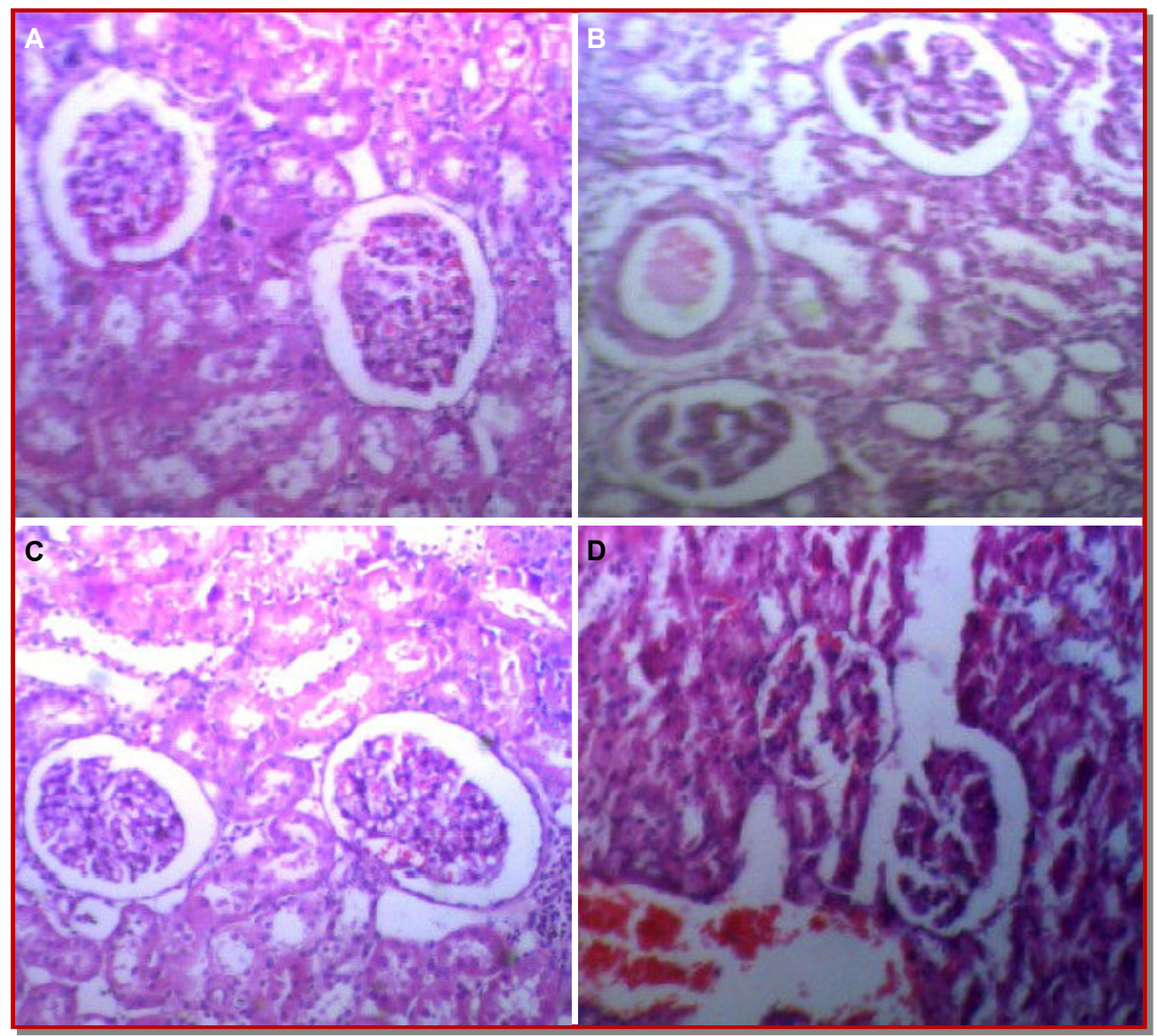

Figure 2: Effect of aqueous extract of leaves of Sechium edule on potassium dichromate-induced nephrotoxicity in rats

A: Normal control; B: Treated with potassium dichromate $(15 \mathrm{mg} / \mathrm{kg}$, s.c.); C: Treated with Sechium edule $(200 \mathrm{mg} / \mathrm{kg})$ and gentamicin $(100 \mathrm{mg} / \mathrm{kg}$, i.p.); D: Treated with Sechium edule (100 mg/ $\mathrm{kg})$ and potassium dichromate $(15 \mathrm{mg} / \mathrm{kg}$, s.c.)

formation of non-protein nitrogenous compound such as urea and creatinine (Punitha et al., 2005). Serum uric acid level was found to be significantly increased in STZ induced diabetic animals. Uric acid clearance has been associated with insulin resistance. Changes in the levels of serum urea, creatinine and uric acid concentrations strongly suggested impairment of kidney function in diabetes. Administration of aqueous extract of leaves of S. edule decreased the levels of serum urea, creatinine, uric acid and protein level in STZ-induced diabetic mice.

\section{Conclusion}

The results of the present investigations shows that the aqueous extract of leaves of $S$. edule has protective effect against gentamicin and $\mathrm{K}_{2} \mathrm{Cr}_{2} \mathrm{O}_{7}$-induced nephrotoxicity and STZ induced diabetic nephropathy.

\section{References}

Albone KS, Gaskin P, MacMillan J, Sponsel VM. Identification and localization of gibberlins in maturing seed of cucurbit
Sechium edule, and a comparison between this cucurbit and the legume Phaseolus coccineus. Planta Springer-verla. 1984; 162: 560-65.

Firdous SM, Sravanthi K, Debnath R, Neraja K. Protective effect of ethanolic extract and its ethylacetate and $n$-butanol fractions of Sechium edule fruits against carbon tetrachloride induced hepatic injury in rats. Int J Pharm Pharm Sci. 2012; 4: 354-59.

Firdous SM, Neraja K, Debnath R, Singha D, Sravanthi K. Evaluation of antiulcer activity of ethanolic extract of Sechium edule fruits in experimental rats. Int J Pharm Pharm Sci. 2012; 4: 374-77.

Franchini I, Mutti A, Cavatorta A, Corradi A, Cosi A, Olivetti G, Borghetti A. Nephrotoxicity of chromium. Remarks on an experimental and epidemiological investigation. Contrib Nephrol. 1978; 10: 98-110.

Gordon EA, Guppy LJ, Nelson M. The antihypertensive effects of the Jamaican Cho-Cho (Sechium edule). West Ind Med J. 2000; 49: 27-31.

Harborne JB. Textbook of phytochemical methods. $1^{\text {st }}$ ed. London, Champraan and Hall Ltd., 1973, pp 110-13.

Harlalka GV, Patil CR, Patil MR. Protective effect of Kalanchoe pinnata pers. (crassulaceae) on gentamicin-induced nephrotoxicity in rats. Indian J Pharmacol. 2007; 39: 201-05. 


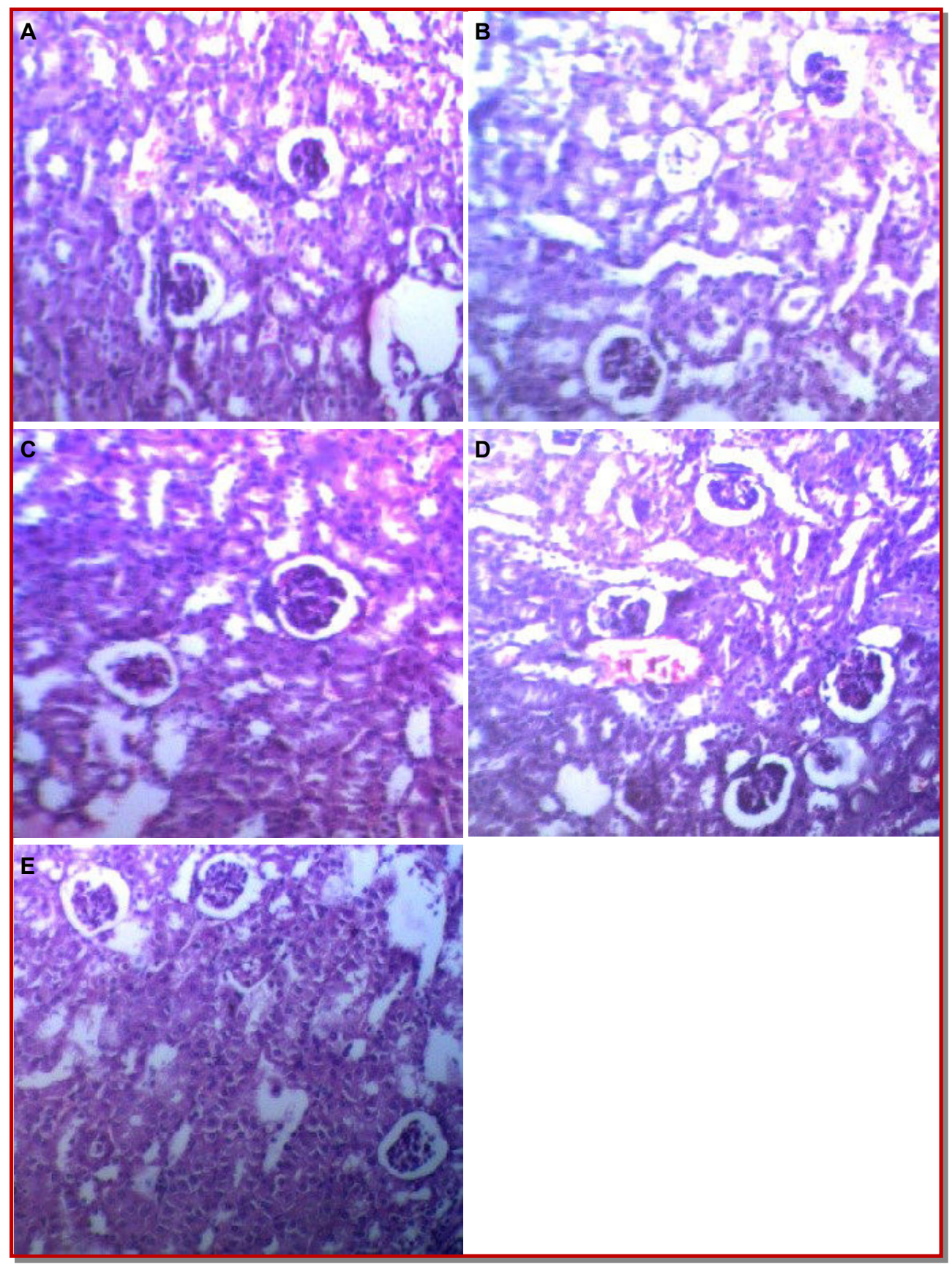

Figure 3: Effect of aqueous extract of leaves of Sechium edule on streptozotocin-induced diabetic nephropathy in mice

A: Normal control; B: Treated with streptozotocin $(55 \mathrm{mg} / \mathrm{kg}$, i.p.); C: Treated with glibenclamide (10 mg/ $\mathrm{kg}$ ) and streptozotocin (55 mg/kg. i.p.); D: Treated with Sechium edule $(200 \mathrm{mg} / \mathrm{kg})$; E: Treated with Sechium edule $(100 \mathrm{mg} / \mathrm{kg})$ and streptozotocin $(55 \mathrm{mg} / \mathrm{kg}$, i.p.)

Kamble MB, Dumbre RK, Rangari VD. Hepatoprotective activity studies of herbal formulations. Int J Green Pharm. 2008; 2: 147-51.

Lelli JL, Becks LL, Dabrowska MI, Hinshaw DB. ATP converts necrosis to apoptosis in oxidant-injured endothelial cells. Free Radic Biol Med. 1998; 25: 694-702.

Parveen K, Khan R, Siddiqui WA. Pycnogenol prevents potassium dichromate (K2Cr2O7)-induced oxidative damage and nephrotoxicity in rats. Chemico-Biol Interact.
2009; 181: 343-50.

Pedraza-Chaverri J, Barrera D, Medina-Campos ON, Carvajal RC, Hernández-Pando R, Macías-Ruvalcaba NA, Maldonado PD, Salcedo MI, Tapia E, Saldívar L, Castilla ME, Ibarra-Rubi ME. Time course study of oxidative and nitrosative stress and anti-oxidant enzymes in $\mathrm{K}_{2} \mathrm{Cr}_{2} \mathrm{O}_{7}$ induced nephrotoxicity. BMC Nephrol. 2005; $26: 4$.

Poormoosavi SM, Behmanesh MA, Najafzadeh H. Effect of cimetidine on gentamicin-losartan induced-nephrotoxicity 
in rats. Afr J Pharm Pharmacol. 2010; 4: 341-45.

Punitha ISR, Shirwaikar A, Shirwaikar A. Antidiabetic activity of benzyl tetra isoquinoline alkaloid berberine in streptozotocin nicotinamide induced type 2 diabetic rats. Diabetologia Croatica. 2005; 34: 117-28.

OECD, 2002. Acute oral toxicity. Acute oral toxic class method guideline 423 adopted 23.03.1996. In: Eleventh Addendum to the OECD guidelines for the testing of chemicals organisation for economic co-operation development, Paris, June, 2000.

Ordonez AA, Gomez JD, Isla MA. Anti-oxidant activities of Sechium edule (Jacq.) Swartz extracts. Food Chem. 2006; 97: 452-58.

Shi X, Chiu A, Chen CT, Halliwell B, Castranova V, Vallyathan $\mathrm{V}$. Reduction of chromium (VI) and its relationship to carcinogenesis. J Toxicol Environ Health. 1999; 2: 87-104.

Siciliano T, De Tommasi N. Study of Flavonoids of Sechium edule (Jacq) swartz (Cucurbitaceae) Different Edible Organs by Liquid Chromatography Photodiode array Mass Spectrometry. J Agric Food Chem. 2004; 52: 6510-15.

Siddiqui O, Sun Y, Lin JC, Chien YW. Facilitated transdermal transport of insulin. J Pharm Sci. 1987; 76: 341-45.

Vozari-Hampe MM, Viegas C, Saucedo C, Rosseto S, Manica GG, Hampe OG. A lectin from Sechium edule fruit exudates. Phytochem. 1992; 31: 1477-80.

Wilson JS, Ganesan K, Palanisamy M. Effect of sinapic acid on biochemical markers and histopathological studies in normal and streptozotocin-induced diabetes in wistar rats. Int J Pharm Pharm Sci. 2011; 3: 115-20. 